\title{
The influence of potential policy measures on the eco-efficiency of personal vehicle mobility in Brussels
}

\author{
N. Sergeant, J. Matheys, J.-M. Timmermans, H. Rombaut \\ \& J. Van Mierlo \\ Department of Electric Engineering and Energy Technology, \\ Vrije Universiteit Brussel, Belgium
}

\begin{abstract}
The finite nature of the oil reserves on the one hand and the growing impact of the use of road vehicles on the air quality and the greenhouse effect on the other hand, require major adjustments of the current vehicle fleet and of its use. Although urban traffic also contributes to resource depletion and climate change, urban areas such as the Brussels Capital Region (BCR) are mainly facing air quality issues. This is due to its dense road network and to the high concentration of receptors (mainly population and buildings). Several possible policy measures could be implemented by the Brussels Regional Government to influence the characteristics or intensity of urban traffic as well as its impact on the environment. These possible policy measures include a reorientation of the fiscal system for vehicles (registration and circulation tax), applying a road or congestion charge, variable parking fees, etc.

The Brussels Regional Government has commissioned a study to investigate the effects of different policy measures on the traffic intensity in the city, as well as on the environment and the eco-efficiency of the vehicle fleet. Other aspects that will be addressed are the implications on the cost per kilometre and how the purchase behaviour, as well as the use of vehicles could evolve.

In this paper, the current situation of urban traffic in the BCR is briefly described, as well as possible policy measures to tackle the issues related to it. Further, the goals of the commissioned study and the proposed methodology are discussed. The Ecoscore, as an important environmental indicator for vehicles, is applied as a tool for policy support.
\end{abstract}

Keywords: mobility, policy measures, Brussels Capital Region, eco-efficiency, Ecoscore, oil dependence. 


\section{Urban mobility: a key issue}

Urban traffic and mobility of goods and people cause important problems in Europe, but at the same time they are some of the most important requisites for the city's well-being. Ensuring accessibility, while protecting quality of life is an essential condition for the further development of the city [1].

As our way of living is continuously changing, our need for mobility continues to increase. The transportation of goods increases as well. These evolutions turned mobility in the BCR into a major issue [2]. People show increasing mobility. Hereby they mainly travel by car with the driver being the only passenger and $25 \%$ of the trips account for less than $5 \mathrm{~km} \mathrm{[1].}$

Vehicle traffic generates increasing nuisance and negatively influences the quality of life of the citizens. The car's share of transportation is excessive: pedestrian zones have been reduced, there is too much "through traffic" in residential areas, public transportation is slowed down due to congestion, etc. [1]. The problems generated by the increased use of motorized vehicles are countless: air and noise pollution, energy use, use of urban area, congestion, accidents, stress, health problems, increased wear out of infrastructure, etc. [2].

The negative influence of urban traffic on different receptors (people, buildings,...) and its various impacts (global warming, air quality) have been demonstrated. Satellite observations of some pollutants (e.g. $\mathrm{NO}_{2}$ ) have shown that Flanders, Brussels and the south of the Netherlands, is one of the most polluted areas in the world, after northern Italy and South-east China [3].

\section{The Brussels Capital Region: inhabitants and commuters}

Since 1989, the Brussels Capital Region (BCR) is an autonomous region in Belgium. It is formed by 19 municipalities and covers $161 \mathrm{~km}^{2}$ (Figure 1). Its 1.031.215 inhabitants (dd 01/01/2007), represent approximately $10 \%$ of the total Belgian population [4]. The urbanized area around Brussels extended strongly during the last 25 years to form a metropolitan area of three million inhabitants.
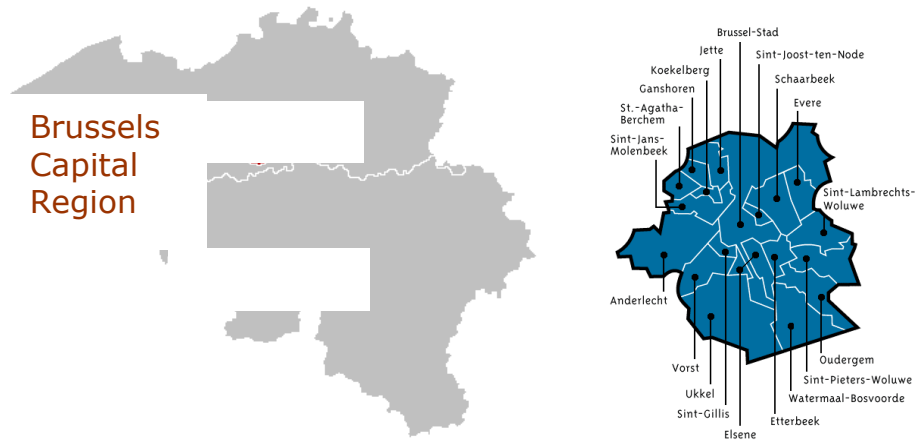

Figure 1: $\quad$ Map of Belgium (left); map of the 19 municipalities of the BCR (right). 
The BCR is the most important employment area in Belgium. In 2006, approximately 667.500 people were working in the BCR. 56\% of the employees are living outside the city and commute to work every day. In the same way, $28 \%$ of the students and pupils that go to school in Brussels live outside the city. Many employees with an average or high income live outside the city. These are also people who often choose to use the car for their daily transportation. This has resulted in an increase of the commuters who travel to the city by car with more than 20\% between 1991 and 2001 [1]. The total road traffic (inhabitants and commuters) in the BCR has increased with more than $17 \%$ between 1990 and 2000 [5].

\section{The vehicle fleet in the BCR: a few statistics}

In $1999,54 \%$ of the families in the BCR owned one car, $14 \%$ even two or more. More than half of the people living in the city use their car as the main mode of transportation for daily travels (Figure 2) [6].
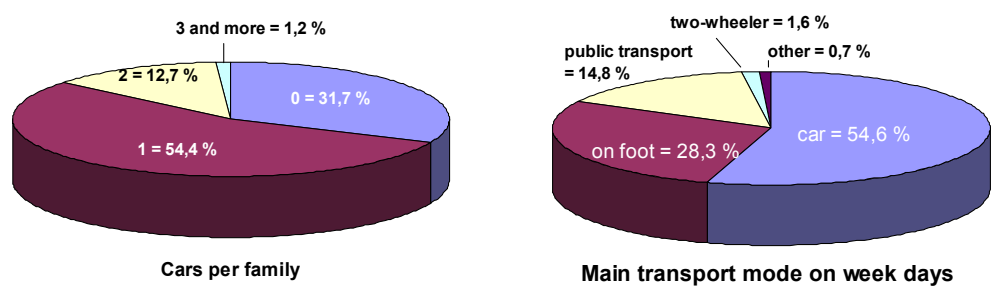

Figure 2: $\quad$ The amount of cars per family in the Brussels Capital Region (left) and the main transportation mode used by inhabitants of the city during week days (right).

The current vehicle fleet of the Brussels Capital Region contains approximately 500.000 vehicles, of which 100.000 are newly registered vehicles (i.e. younger than one year). Looking at the composition of the car park regarding vehicle technologies, the majority of the vehicles use diesel as a fuel (53\%), followed by petrol (46\%). The remaining $1 \%$ is covered by LPG, CNG and a few battery electric vehicles. For new vehicles, the share of diesel vehicles is even larger, namely $82 \%$. The car fleet in BCR and in Belgium in general, shows a strong evolution towards diesel cars in recent years. Despite this evolution and the strong environmental and health depleting impact of diesel due to the emissions of particulate matter and nitrogen oxides, the environmental performance of the car fleet is improving. New vehicles have to comply with the ever more stringent Euro standards, which make them emit less harmful emissions compared to older, similar models. This positive evolution can be quantified and analysed using the Ecoscore methodology (see chapter 5.1) to study the car fleet in the BCR, which increased with one point from 2006 to 2007 to an average score of 52,6 [7]. 
An indication of the vehicle use in the BCR can be given by the yearly amount of traveled vehicle or passenger kilometers. In 2006, 3,28 billion vehicle kilometers were traveled, an increase of $0,3 \%$ compared to the previous year. Compared to 2005 , the amount of passenger kilometers has increased with $1,0 \%$ to a number of 4,22 billion [5].

\section{Policy measures to improve mobility: a look at other cities}

\subsection{Introduction}

Several cities and countries have already applied specific policy instruments to induce a shift towards other modes of transportation, towards the use of 'cleaner' vehicles or to reduce traffic flows. Some of these measures have already proven their efficiency, others are being evaluated. Some of these measures already take into account the environmental impact of the vehicle, which is defined in different ways for the different countries and cities. Many different measures exist to obtain these results, they can be generally classified into three categories: pricing instruments (fiscal measures, road pricing and subsidies), mandates (car industry, public and private fleets) and collaborative instruments (voluntary agreements and user (dis)advantages) [8]. A few of these policy measures, which were found to be interesting for this study, will be briefly discussed hereafter.

\subsection{Fiscal measures}

Car taxation can be divided into three types: (1) acquisition taxes paid at the purchase or registration of a car; (2) ownership taxes which are paid annually (circulation tax) and (3) taxes related to the use of a car (excise duties, road taxes).

Transport related taxes are significant in the total fiscal income of Belgium (1,5\%, excluding fuel taxes). Transport fuel taxes represent another $3 \%$ of the total tax income in Belgium [9]. In the European Union there's a trend towards reducing the income of car taxes (especially registration taxes) in favour of road pricing [10]. A new European directive on car taxation has been proposed, focusing on the $\mathrm{CO}_{2}$ emissions of passenger cars [11]. In Germany, the annual circulation tax is based on the emission standard of the vehicle. In the Netherlands, an additional registration tax is implemented since January 2008 for vehicles with high $\mathrm{CO}_{2}$ emissions. A reduction is provided for diesel vehicles equipped with a particulate filter. In the $\mathrm{UK}$, the $\mathrm{CO}_{2}$ emissions of a vehicle are used as the basis of the annual circulation tax for new passenger cars. Other fiscal incentives exist as well, for instance the company car taxation based on the $\mathrm{CO}_{2}$ emissions of the vehicle, as can be seen in Belgium and in the UK [8].

In Belgium, car taxation is currently based on a specifically defined parameter, 'fiscal horsepower' (which is calculated from the motor's cylinder capacity) and the engine power of the car. With the registration of a car, a registration tax is paid. A circulation tax is paid annually. Since 2007, a direct reduction on the purchase price for private passenger cars with low $\mathrm{CO}_{2}$ 
emissions is granted by the Belgian government [12]. The three regional authorities (Brussels, Flanders and Wallonia) are authorized to change the car taxation, but a principal agreement exists between the regions not to make unilateral changes to the car taxation system. In 2009, the regions will also be authorized to receive the income of the car taxation. The government of the Flemish region already announced its intention to change the system of car taxation by linking it to the environmental performance of the vehicle, indicated by the Ecoscore [13].

\subsection{Road pricing}

Road pricing is a mechanism which can encourage reductions in vehicle travel and shifts towards other modes of travel. The most common types of road pricing are based on distance, place and/or time. These measures change the variable cost of driving either per kilometer, per time of day or per trip. In this case, the variable cost is expressed as roadway use fees that amount to a toll either for each unit of distance traveled, either for the entry into a specific area.

Although the purchase cost of a vehicle, which is a fixed cost, represents a large part of the costs associated with owning and operating a vehicle, it is not likely to be part of the decision whether to make a particular trip or not. By shifting some of these fixed costs to variable ones, a much stronger signal could be sent to drivers regarding the real costs of each trip [14]. This in turn may encourage reductions in vehicle use and induce a modal shift. If pricing is implemented for travel on specific routes, at specific times, it may encourage drivers to switch the route or time of particular trips. Such a targeted approach may be very useful for reducing congestion and eliminating traffic bottlenecks. Moreover, when benefits are given to drivers of clean vehicles, e.g. lower tolls, a higher share of clean vehicles using the route or entering the city may be expected [8].

Instruments of this category of pricing measures have been applied in several European countries and cities. Switzerland was the first European country to introduce an automatic tolling system for heavy duty vehicles in 2001 on all Swiss roads. In Germany, an electronic tolling system for heavy goods vehicles has been introduced in 2005, covering its entire highway network [15]. A similar system has been introduced in Austria for heavy duty vehicles on the highways, but without considering any environmental parameter [16]. In the Netherlands, a so-called 'kilometer charge' will be introduced in 2011, on all roads for all vehicles. In a first phase, toll rates will only be differentiated according to the environmental class of the vehicle, in a next phase, also the time of day and type of road might be taken into account [17].

A specific kind of road charging is the so-called 'cordon-based charge'. The best known example of this system is the London 'congestion charge', which was introduced in 2003. This system implies that a daily charge has to be paid by vehicles on public roads in the congestion charge zone on week days, between 7 am and $6 \mathrm{pm}$. While residents of the zone receive a $90 \%$ discount, some vehicle categories and/or drivers are exempted from the charge, including environmentally friendly vehicles [18]. This measure reduces traffic levels, while 
contributing to reduce vehicle emissions. The revenues can be used to fund public transportation alternatives. Stockholm has introduced a similar congestion charging system in 2006-2007.

\subsection{User (dis)advantages}

Local authorities can implement a set of initiatives to promote clean means of transportation and a more sustainable environment, often defined as user (dis)advantages. User advantages can aim at offering benefits to people driving clean vehicles. In general, the benefits are of financial nature. A common example of such a measure, are reduced parking fees for clean vehicles. In general, variable parking fees can be designed to target certain groups or types of vehicles. These might be single occupant vehicles or commuters, who can be targeted by raising parking prices during peak hours. Another approach, which is starting to become more and more prevalent, is differentiating parking fees based on the environmental impact of the vehicle. This measure has been applied in several Swedish cities (e.g. Stockholm, Göteborg) where clean vehicles are exempted or pay reduced parking fees [19].

User disadvantages have the aim to discourage the use of environmentally unfriendly vehicles. This can be obtained by e.g. prohibiting the entrance to a certain area and/or at a certain time, generally city centers, of vehicles not corresponding to a minimum emission standard. Restricted areas are implemented to increase air quality, reduce noise and decrease congestion [20]. Examples in Europe are mainly targeted at heavy duty vehicles (e.g. Prague, cities in Sweden and the Netherlands). The selective admittance policy is usually based on a technical requirement of the vehicles, such as the emission standard (e.g. Amsterdam), presence of a particulate filter (e.g. Utrecht), load capacity (e.g. Prague, Copenhagen), etc. Benefits of this measure will increase when light duty vehicles are included: the effect on air quality is significantly higher and revenues due to enforcement increase [20,21]. In Italy, many cities (e.g. Rome, Turin, Alba) have installed restricted areas for light duty vehicles and motorized two-wheelers with the aim to decrease air pollution and traffic flows as well as to preserve the city's historic character [20,22,23]. In Germany some cities (e.g. Berlin, Stuttgart, Frankfurt, Munich and Cologne) are implementing restricted areas for vehicles not complying with previously defined particle emission standards. Vehicle owners are obliged to mark their vehicle with a sticker, of which the colour indicates the particle emission level [24].

\subsection{Policy measures: conclusion}

According to Gordon [25], a package of sound fiscal policies, accompanied by a strong regulatory policy, is necessary to steer the market towards cleaner vehicles. A mix of policies which integrate carrots (incentives), sticks (disincentives) and regulations works best. These should be aimed at industry and final consumers, both public and private. For private consumers, tax systems based on the environmental performance of the vehicle become more and more common. For private fleet consumers, only voluntary systems are in place today. 
Company car taxation seems to be the appropriate instrument to influence that market. For public consumers, mandatory targets for clean vehicles seem to have an effect on the overall market and are a suitable instrument to open the market. Looking at the past three years, classic car taxation paid for ownership of a car is decreasing in favour of road charging systems. Classic subsidy programs are being abolished because they are no longer in line with European legislation on this matter [8].

\section{The influence of policy measures on the Brussels' mobility}

The Brussels Capital Region has several possible policy instruments at its disposition to influence the urban traffic and its environmental impact, e.g. a new fiscal system for vehicles (registration and circulation tax), a congestion charge or road charge, variable parking fees, etc.

The Brussels regional government commissioned a study to investigate the effects of such measures on the traffic intensity in the city, as well as on the environment and the eco-efficiency of the vehicle fleet. Other aspects that will be addressed are the implications on the cost per kilometer and how the purchase behaviour as well as the use of vehicles will evolve.

In this study, a methodology is being developed, databases are being built and analyses are performed to obtain a thorough insight on the impact of policy measures on the traffic in Brussels. Therefore it is necessary to consider the environmental performance (eco-efficiency and Ecoscore), the dependence on imported energy sources and the energy efficiency of existing vehicles, as well as of vehicles with alternative fuels and/or drive trains (bio-fuels, CNG, LPG and (hybrid) electric vehicles). Finally, an important social parameter is the cost per kilometer, which depends among others on the (new) fiscal policy, increasing fuel prices, purchase price of a (new) vehicle, etc. For these different elements, indicators are being developed that are based on the technology as well as on the use (mileage) of the vehicles.

\subsection{Development of indicators}

A methodology is being developed to analyze the different selected policy measure scenarios on the vehicle fleet databases. Different indicators need to be developed: an indicator to assess the energy efficiency and energy dependence of the vehicle fleet, as well as an indicator for the cost per kilometer. An environmental indicator to assess the eco-efficiency of the vehicle fleet will be the Ecoscore indicator.

The Vrije Universiteit Brussel, together with other partners, has developed the Ecoscore methodology [26], a well-to-wheel environmental rating tool for road vehicles, in commission of the Flemish government. The tool has been developed to support different policy measures to promote the purchase and use of cleaner vehicles.

The Ecoscore tool makes it possible to calculate an "environmental score" for every individual vehicle. Different damage effects are taken into account: 
climate change, air quality depletion (health impairing effects and effects on ecosystems) and noise pollution. The methodology is based on a well-to-wheel analysis, which means that besides tailpipe emissions, the air pollution caused by the production and distribution of the fuel is also taken into account. This allows us to compare different vehicle technologies and fuels [26].

In this project, the Ecoscore will be used to assess the eco-efficiency of the vehicle fleet (inhabitants and commuters), taking into account the mileage of the vehicle fleet.

\subsection{Database development}

Databases are being developed to perform the necessary analyses of the vehicle fleet. These databases contain an inventory of the current vehicle fleet, with potential projections towards the future. These data will be coupled with the Ecoscore database, which consists of all vehicle models available on the Belgian market, with their corresponding technical en environmental data.

\subsection{Scenario development}

Based on a literature search, different policy measures are being selected that can be applied in the BCR. These measures might be: a new fiscal system for passenger vehicles and company cars, a congestion or road charge, variable parking fees, etc. Different scenarios are being developed for each of these measures.

\subsection{Analysis of the vehicle fleet in Brussels}

Based on the developed indicators, the composed databases and the selected scenarios, different analyses will be made of the vehicle fleet in Brussels. This comprises an analysis of the vehicle fleet (inhabitants and commuters) regarding its eco-efficiency, energy efficiency and dependence, and cost per kilometer. The Ecoscore will be the most important indicator in these analyses.

Finally, the obtained results and the used hypotheses from the previous steps will be the subject of a sensitivity analysis. This analysis must allow investigating the influence of the accuracy of the input data on the environmental analyses. Moreover, these analyses will allow examining the influence of the model parameters and the robustness of the developed methodology. This will allow validating the obtained results of the research project.

\section{Conclusion}

The Brussels Capital Region is a densely populated area, with a high degree of motorization and a large flow of commuters entering the city daily. This resulted in a large congestion problem, with its related consequences regarding air quality and noise, which effect a high concentration of receptors (mainly population and buildings). Policy makers have the possibility to implement different measures to tackle these issues and to maintain or improve the quality of life in the city. 
These measures can be classified into three categories: pricing instruments (fiscal measures, road pricing and subsidies), mandates (car industry, public and private fleets) and collaborative instruments (voluntary agreements and user (dis)advantages). A few of these instruments, which have already been applied in other European cities, have been described in this paper. These include a reorientation of the fiscal system for vehicles (registration and circulation tax), applying a road or congestion charge, variable parking fees, restricted areas or low emission zones, etc.

The Brussels regional government has commissioned a study to investigate the effects of different policy measures on the traffic intensity in the city, as well as on the environment and the eco-efficiency of the vehicle fleet. Other aspects that are being addressed are the implications on the cost per kilometer and how the purchase behaviour, as well as the use of vehicles could evolve. After a literature review of existing policy measures and indicators, databases are being built and scenarios are being drawn. In a next phase, the necessary indicators will be developed to analyze the impact of the policy scenarios on the environmental performance, fossil fuel dependence, energy efficiency and cost per kilometer of the vehicle fleet in Brussels. An important parameter will be the Ecoscore, an environmental indicator based on the vehicle's well-to-wheel emissions and fuel consumption.

\section{Acknowledgement}

The authors would like to thank the Institute for the Encouragement of Scientific Research and Innovation of Brussels (IWOIB-IRSIB) for financing this study.

\section{References}

[1] Ministry of Brussels Capital Region, Bestuur Uitrusting en Vervoer (BUV), Gewestelijk Vervoerplan: Stand van zaken van de mobiliteit in Brussel, Mobil 2015, 2006, www.iris2.irisnet.be/Public.

[2] Brussels Environment (IBGE-BIM). Mobility in Brussels, www.ibgebim.be.

[3] Beirle, S., Platt, U., Wenig, M. \& Wagner, T., Weekly cycle of $\mathrm{NO}_{2}$ by GOME measurements: a signature of anthropogenic sources. Atmospheric Chemistry and Physics, 3, pp. 2225-2232, 2003.

[4] Brussels Capital Region, www.bruxelles.irisnet.be.

[5] Statistics in Belgium (Statbel), statbel.fgov.be.

[6] First national survey on mobility, financed by POD Wetenschapsbeleid, BCR and Walloon Region, realised by the Groupe de Recherche sur les Transports des Facultés Universitaires Notre-Dame de la Paix (coördinator), Langzaam Verkeer, l'Institut Wallon, de Universitaire Instelling Antwerpen en de Algemene Directie Statistiek, 1998-1999.

[7] Macharis, C., Turcksin, L., Van Mierlo, J., Sergeant, N., Wynen, V. Jourquin, B., Govaerts, L. \& Denys, T., Modalities of the reformation of the traffic and registration tax based on the environmental performance of 
vehicles. Final report of the project commissioned by the Brussels Capital Region, 2007.

[8] Denys, T. \& Govaerts, L., Overview of policy measures. Report of CLEVER - Clean vehicle research: LCA and policy measures, project commissioned by the Belgian Science Policy (Belspo), 2007.

[9] European Commission, Impact assessment - annex to the proposal for a Council Directive on passenger car related taxes. Commission Staff working documents SEC(2005)809, 2005.

[10] Eurostat, Taxation trends in the European Union. Eurostat Publication 2007, 2007.

[11] European Commission, Proposal for a Council Directive on passenger car related taxes. COM(2005)261, 2005.

[12] Royal Decree, Bepaling van de regels voor de toekenning van een korting voor de verwerving van een voertuig met een maximale uitstoot van 115 gram $\mathrm{CO}_{2}$ per kilometre en van een dieselvoertuig standard uitgerust met een roetfilter. Royal Decree of 8 June 2007, 2007.

[13] Flanders, Ecoscore als basis voor de verkeersbelastingen. Press communication of the Flemish Government, 20 July 2006.

[14] International Energy Agency, Saving oil and reducing $\mathrm{CO}_{2}$ emissions in transport - Options and strategies. IEA, Paris, France, 2001.

[15] Toll-Collect. Toll-Collect, Service on the road. www.toll-collect.de.

[16] Oehry, B., Charging technology and cost effectiveness. Proceedings Conference on Road Charging Systems: Technology Choice and Cost Effectiveness. ECMT, Paris, 2006.

[17] Eurlings, C., Tekst video persconferentie kilometerheffing. Minister of Transport, Public works and water management of the Netherlands/ www.verkeerenwaterstaat.nl.

[18] Transport for London. Congestion charging. www.tfl.gov.uk.

[19] Blom, M.J., Schroten, A., Van Essen, H.P., Milieueffecten van differentiëren van parkeertarieven. Delft, CE, 2006.

[20] Hoogma, R., Van de Laar, R. \& Motshagen, R., Eindrapportage Milieuzones in Nederlandse steden. Novem, 2003.

[21] AEA Technology Environment, The London Low Emission Zone Feasibility Study, Phase 2. AEA Technology Environment, 2003.

[22] Torino, www.comune.torino.it .

[23] Alba, www.comune.alba.cn.it.

[24] Donner, S., Die Feinstaubplakette. Aktueller begriff, Deutscher Bundestag, Wissenschaftliche Dienste, nr. 26/06, 2006.

[25] Gordon, D., Fiscal policies for sustainable transportation: international best practices. Report prepared for the Energy Foundation and the Hewlett Foundation, 2005.

[26] Timmermans, J.-M., Matheys, J., Van Mierlo, J. \& Lataire, Ph., Environmental rating of vehicles with different fuels and drive trains: a univocal and applicable methodology. European Journal of Transport and Infrastructure Research, 6 (4), pp. 313-334, 2006. 